\title{
Analysis Factors Supporting and Inhibiting Principal in Promoting Guidance and Counselling Teacher in 7State Senior High School Sarolangun
}

\author{
Siti Rofiqoh \\ Magister Candidate for Education Management at Institut Agama Islam Negeri Sulthan Thaha Saefuddin Jambi
}

\begin{abstract}
One of the principal tasks is to lead all teachers, staff and students at the school. In a leadership role, then the task of a school principal is to foster namely: assist, encourage and give confidence to teachers and ensure that teaching and learning can provide the development of a wide range of experience, knowledge, attitudes and skills of teachers, and the learning process carried out by the teacher must assisted in a professional manner so that teachers can thrive in a job which is to improve the effectiveness and efficiency of the learning process. The purpose of this research is to answer the question (1) what are the factors supporting and coaching principals in guidance and counseling teacher ?, and (2) any efforts made by the principal in guidance counseling and guidance teachers?. Research with qualitative approach is to obtain information that the motivating factors in coaching principals to Guidance and Counselling Teacher at SMAN 7 Sarolangun are: (1) Human resources (HR) adequate, (2) infrastructure is inadequate and (3) potential students. While the factors inhibiting the process of coaching Guidance and Counselling teachers by principals are: (1) the number of Guidance and Counselling Teacher limited (4), so that does not meet the ideal ratio, (2) infrastructure Guidance and Counselling inadequate (no special room counseling), (3) the age of Guidance and Counselling Teacher over the productive age, so often did not attend the execution time coaching due to illness, licenses and training. The activities coaching is done by the principal are: (1) Provision of landing when the apple in the morning, (2) The directives and guidance as incidental if there is activity, (3) Principal participate to socializedof Guidance and Counselling, (4) Involve teachers seminars, (5) Facilitating Guidance and Counselling services infrastructure in schools, (6) Monitoring activities of Guidance and Counselling, (7) Evaluate the work of Guidance and Counselling Teacher, (8) Ask Guidance and Counselling program activities.
\end{abstract}

Keywords: Development, Head of School, Guidance and Counselling Teacher, SMAN 7 Sarolangun

\section{Introduction}

Efforts to improve the quality of education continues to be done by the government. These efforts can be seen from the increase of financing of education, training of teachers, curriculum change, improved infrastructure, and so on. But has not shown encouraging results, even many failures in implementing in the field. Failure is partly the lack of proper management problems, staffing issues do not correspond with the areas of expertise, and to tackle the problem not by experts so that the national education goals for the intellectual life of the nation through quality improvement in every type and level of education cannot be realized.

Schools as institutions have a crucial role in enhancing the quality of education. School is a place for the occurrence of the educational process is learning and teaching. Good teaching and learning process will have a positive impact on the quality of education in general. In addition, the school is also a place to socialize human (teachers, students, principals and staff) with a variety of backgrounds. Brief said the school is a miniature society. Therefore, it can be said that the school is the most important place in improving the quality of education.

As a place for teaching and learning process (the process of education) schools have components that are important and interrelated. The components in an institution (school), among others: students, teachers, principals, staff, facilities and infrastructure and the school environment. These all components cannot be separated and stand on their own. Therefore, to improve the quality of education, all components must be understood, addressed and managed appropriately.

As described above, one important component in improving the quality of education at school level was the principal. The school principal is the educational leader level educational units must have a solid foundation of leadership. To that end, according to Mulyasa (2013) each of the principal should understand the key to leadership success, among which are: the importance of school leadership, school leadership indicators, and expectations of teachers to principals.

One of the principal tasks is to lead all teachers, staff and students at the school. In a leadership role, then the task of a school principal is to foster namely: assist, encourage and give confidence to teachers and ensure that teaching and learning can provide the development of a wide range of experience, knowledge, attitudes and skills of teachers, and the learning process carried out by the teacher must assisted in a professional manner so that teachers can thrive in a job which is to improve the effectiveness and efficiency of the learning process. According to Imron (1995) guidance of teachers is often interpreted as a relief effort given to teachers who primarily intangible professional services performed by principals or supervisors (superintendent) of the school to improve student learning outcomes.

As for the definition of teacher coaching by Sukirman (2008) is the work done to promote and improve the quality and efficiency of the entire force personnel in the school environment. In the large dictionary Indonesian (Peorwadarmita, 1987) mentioned that coaching is a business, actions and activities carried out efficiently and 


\section{International Journal of Science and Research (IJSR) \\ ISSN (Online): 2319-7064}

Index Copernicus Value (2013): 6.14 | Impact Factor (2015): 6.391

successfully in order to obtain better results, while according Thoha (1989) coaching is a process, results or questions for the better, in this case embodies the change, progress, improvement, growth, or evaluating various possibilities for something.

Coaching is basically concerned with the functions and efforts to improve the effectiveness and efficiency of the humans in the process of cooperation to achieve common goals, it is mainly through efforts to create an atmosphere or a working environment that can push to develop the potential optimally, The purpose of coaching is structured to develop the ability to carry out the duties and functions to be better and more effective and requires a broader view, skills and abilities better. Therefore, the guidance provided by principles in the school, should be able to improve the ability of teachers, which includes knowledge, insight, creativity, commitment, and discipline, so that teaching and learning in school can take place properly, efficiently and successfully order.

According Risaldi (2015) guidance is a process of providing assistance to individuals on an ongoing basis and systematic, carried out by an expert who has received special training for it, is that people can understand themselves and the environment, to be able to develop their potential optimally. As according Prayitno (2010) counseling is the process of providing assistance through interviews by a counselor counseling to clients who are experiencing the problem boils down to overcome the problems faced by the client. Thus it can be understood that the guidance and counseling intended to help individuals develop themselves optimally match the stage of development and its predisposition such basic abilities and talents, diverse backgrounds that exist such as family background, education, social, and economic. Counseling also helps individuals to become independent beings who have the ability to understand themselves and the environment, able to take appropriate decisions and be able to develop skills. Guidance and counselling materials, including teaching materials that are more focused on the enrichment of knowledge (cognitive) and minimal in the formation of attitudes (affective), as well as habituation (psychomotor).

The general objective of guidance and counseling services according to the Law on National Education System (UUSPN) of 1989 (Law No. 2/1989), namely the creation of fully human Indonesia intelligent, the faithful, and devoted to God Almighty and noble character, have knowledge and skills, physical and spiritual health, steady and independent personality and sense of social responsibility and nationality (Department of Education, 1994). While the specific purpose of guidance and counseling services is to help students to achieve development objectives include aspects of personal, social, learning and career. Personal-social guidance is intended to achieve the objectives and tasks of personal-social development in the realization of personal piety, independent, and responsible. Tutoring is intended to achieve the objectives and tasks of educational development. Career guidance is intended to bring private productive worker.
Associated with the purpose of fostering teachers by the school principal, the teachers in the coaching process takes several techniques that the coaching process can be run in accordance with the goals and objectives set has done. Some teachers coaching techniques that can be done by the principal according to Imron (1995), among others: classroom visits, private meetings, board meetings of teachers, visits between classes, school visits, meetings between working groups, professional publishing and education and training. Of these techniques, principals can pick and choose the most appropriate technique and according to the circumstances of each school. With the right coaching techniques, the process of guidance and counseling done by Guidance and Counselling Teacher will run effectively and efficiently.

The effectiveness and efficiency of the guidance and counseling teacher has many benefits as mentioned by Efastri, et al. (2015) that the implementation of guidance and counseling in schools can effectively reduce bullying and aggressive behaviors in students. As according Authority (2015) stated that guidance and counseling by modeling techniques can improve discipline of high school students in Lamongan.

Coaching teachers by the principal is a very important process. The coaching process can improve the competence and expertise of teachers in performing the task. This is in line with the opinion of Purwanto (2008), in his research he found that coaching principals can improve the performance of teachers in the district of South Purwokerto by enhancingreach of $74.97 \%$. Additionally, Rohim (2011) also mentions that the development of teachers by principals can improve coordination and cooperation between teachers in the school.

Based on the background of the problem, the problem of this research are: (1) what are the factors supporting and coaching principals in guidance and counseling teacher? (2) any efforts made by the school head teacher in guidance counseling and guidance?

\section{Research Methodology}

The methods used to obtain the data in this study is a qualitative approach. Qualitative research methods are often called naturalistic research methods for research conducted on natural conditions, also known as qualitative methods for the data collected and analysis is qualitative (Sugiyono: 2008). The research location is at SMAN 7 Sarolangun. The primary data in this study is data obtained from high school managers, teachers and learners in the form of information, relating to: 1) what are the factors supporting and principals in guidance counseling and guidance teachers, 2) what are the efforts of principals in guidance counseling and guidance teachers.

Data collection techniques in research in this study was the observation participate (participant observation), in-depth interviews (in-depth interviews) and documentation. In this study the authors use data analysis model of Miles and Huberman. Data analysis in qualitative research, carried out at the time of data collection takes place, and after the 


\section{International Journal of Science and Research (IJSR) \\ ISSN (Online): 2319-7064}

Index Copernicus Value (2013): 6.14 | Impact Factor (2015): 6.391

completion of data collection in a particular period. Miles and Huberman argued that the activity in qualitative data analysis performed interactively and runs continuously until complete, so that the data is already saturated.

\section{Data and Discussion}

\subsection{Factors inhibiting and supporting principals in guidance counseling and guidance teachers.}

The journey of a process of education will certainly find the factors supporting and factors become an obstacle. Their supporting factor is certainly a positive impact because it will be very helpfully in goal achievement process of education but not so with the inhibiting factor. The inhibiting factor as much as possible to be overcome and a solution that does not disrupt the educational process. So also in coaching principals to Guidance and Counselling Teacher. From the research conducted, there are several factors that supporting and there is also a barrier.

\section{Supporting Factor}

Factors supporting the development of guidance and counseling teacher at SMAN 7 Sarolangun are:

\section{a) Human Resources (HR)}

High school (SMA) Country 7 Sarolangun have adequate human resources. SMAN 7 Sarolangun supported by SDM are educated to degree level with a wide range of disciplines and teaching in accordance with their respective disciplines. Even today there are few teachers have completed advanced studies program S2. SDM with high educational background would be very helpful in organizing the educational process and to respond to these developments and changes that occur in particular in the development of the guidance and counseling teachers and principals have been trying to persuade teachers to be actively involved

b) Facilities and infrastructure.

Infrastructure owned SMAN 7 Sarolangun perceived by the teacher is to help smooth in coaching, SMAN 7 Sarolangun have laboratories, a library with various collections of books and others. From field observations in the implementation of coaching principals to Guidance and Counselling Teacher, still lack the utilization in terms of facilities and infrastructure by the principal, is still their less creative and innovative, in conducting the counseling process, because there are no special counseling room.

\section{c) Potential students}

Students at SMAN 7 Sarolangun has the potential to be empowered as evidenced by the accomplishments they achieved in activities such as race group counseling and individual counseling, although with facilities and infrastructure by pickup only.

Based on the supporting factors in implementing guidance counseling teacher by the principal as described above, it is understood that in general the whole of this potential can be used optimally. SMAN 7 Sarolangun who already have adequate human resources is the primary resource. With such resources, the principal can actively involve all available resources to plan, implement and evaluate school programs include teacher training programs in Guidance and
Counselling. With human resources, enabling the planning, implementation and evaluation that there is a quality process.

Infrastructure is a very important factor in the educational process included in the process of coaching guidance and counselling teacher. Adequate facilities and infrastructure that will facilitate the principal in carrying out its duties as manager BK teachers, as well as for teachers will facilitate the implementation of the tasks Guidance and Counselling teachers. Facilities and infrastructure owned SMAN 7 Sarolangun perceived by the teacher is to help smooth the guidance of teachers by principals. In fostering BK teachers, principals need to take advantage of all the facilities and infrastructure that exist with the right teacher, creative and innovative manner.

In addition to human resources and infrastructure teachers, SMAN 7 Sarolangun also has the potential to become empowered others are students. In general it can be said that high school students aged 14 to 18 years are productive with all age ranges of characteristics. In addition, the number of students to 600 students a high number to be managed. With the large number of students, the school students also have much to gain various achievements and level of government. Therefore, it is a very good potential.

Guidance and Counseling Teacher linked with the coaching of teachers, the number of students that much, the productive age range and number of student achievement is the potential that can be used by the school principal. In fostering guidance and counseling teachers, principals can utilize student achievement as a means for practicing teachers to prepare planning guidance and counseling right coaching for student achievement. Likewise, the persistence of students who do not/did not do well, principals can encourage teachers to compile Guidance and Counselling Teacher coaching programs that can be used to improve student achievement. The number of students can also be used to encourage Guidance and Counselling Teacher teachers in preparing students coaching program, for example, interest and talent development programs, coaching or troubled students with special needs and so on.

\section{Obstacles}

Potential inhibitor is a weakness and challenges of coaching principals toguidance and counselling teachers in SMA 7 Sarolangun. Based on the findings in the field there are several factors that become an obstacle. As for the obstacle in the formation of the head of the teachers' guidance and counseling at SMAN 7 Sarolangun are: (1) the number of Guidance and Counselling Teacher limited (4), so that does not meet the ideal ratio, (2)infrastructure BK inadequate (no special counseling room), (3) the age of Guidance and Counselling Teacher over the productive age, so often did not attend the execution time coaching due to illness, licenses and training.

Based inhibiting factor as described above, it is understood that these factors include external. The external factors in question are factors that come from outside the school heads concerned. Therefore, to overcome the barriers that come from outside (external factors) required negotiation skills, 


\section{International Journal of Science and Research (IJSR) \\ ISSN (Online): 2319-7064}

Index Copernicus Value (2013): 6.14 | Impact Factor (2015): 6.391

the ability to lobby with the relevant parties to participate resolve the issue. Related parties in question in this case is the government. It is well known that the authority of the appointment of teachers, including Guidance and Counselling Teacher and compliance counseling facilities is a government authority. Thus the principal should immediately submit the matter to the government to keep working to find an alternative solution.

\subsection{Efforts made in coaching school principal teacher of guidance and counseling}

Coaching is an activity undertaken to obtain better results with the help of the form of guidance, supervision and encouragement. With the help of the expected results of coaching can be efficient and effective. Description of data about development efforts undertaken by the principal to improve guidance and counselling teacher competence, obtained through interviews with respondents of the study. Based on interviews, performance counseling teacher at SMAN 7 Sarolangun is good, it can be seen from the shape of the real performance of teachers in the school. As the performance of guidance and counselling Teacher classical look of implementation services, individual counseling services and calling the troubled student, guidance and counselling teacher runs absent students on a daily basis and also call the student in question. As well as providing information about careers and jobs.

The school principal is a principal officer in the organization and administration of services BK in school. He plays an important and decisive, both as leader of the school, as well as a member of the guidance council. The school principal training and coaching to Guidance and Counselling Teacher accordance with the level of understanding of each school principal to the implementation of the BK in school. Suppose guidance and counselling teacher to follow program deliberation teacher guidance and counseling (MGBK), which is held every two months. Then this happens because they found principals who do not understand how implementation of the guidance and counsellingin school.

\section{Coaching Program conducted by the Principal}

Based on the results of interviews with several Guidance and Counselling Teacher at SMAN 7 Sarolangun obtained information that in fostering the guidance and counselling teachers there are several development activities carried out by the principal. Activities coaching is done by the principal are: (1) Provision of landing when the apple in the morning, (2) The directives and guidance as incidental if there is activity, (3) Principal participate popularize guidance and counselling programs, (4) Involve teachers in the seminar, (5) Facilitating guidance and counselling services infrastructure in schools, (6) Monitoring activities of guidance and counselling service, (7) Evaluate the work of Guidance and Counselling Teacher, (8) Ask guidance and counselling teacher program activities.

Associated with the description of the forms of guidance counseling teacher by the principal as described above, it is understood that can be generally grouped into two groups: personal coaching and coaching or fulfillment service facilities guidance and counselling servive. Personal coaching in teacher training related to scientific guidance and counselling and guidance so that the counselling teachers work productivity. Personal coaching include: granting landing during morning assembly, direction and coaching incidental, send of Guidance and Counselling Teacher in educational seminars, to monitor the activities of teachers and evaluate the work of Guidance and Counselling Teacher. As for the coaching fulfillment facilities include compliance infrastructure of guidance and counselling servive.

Based on the above, which is associated with the principal efforts in fostering a counseling teacher at SMAN 7 Sarolangun in general has been varied. However, efforts to teacher training as described have not been fully successful. Guidance and counselling has not been successful coaching of teachers by principals existence because of several barriers experienced by principals in fostering. Therefore, in fostering guidance and counselling teachers, principals need to conduct studies in a more mature and profound obstacles related to the most crucial, so it needs to be addressed immediately.

\section{Conclusions and Recommendations}

\subsection{Conclusion}

Based on the analysis of empirical facts that occurred in SMAN 7 Sarolangun. It can be three conclusions are:

1. Factor supporters in coaching principals to Guidance and Counselling Teacher at SMAN 7 Sarolangun are: (1) Human resources (HR) adequate, (2) the availability of facilities and infrastructure in general, and (3) students with all their characteristics. While the factors inhibiting the process of coaching guidance and counselling teachers by principals are: (1) the number of guidance and counselling teacher limited (4), so that does not meet the ideal ratio, (2) infrastructure guidance and counsellinginadequate (no special room counseling), (3) the age of Guidance and Counselling Teacher over the productive age, so often did not attend the execution time coaching due to illness, licenses and training.

\subsection{Suggestion}

Based on the factors supporting and principals in doing coaching of Guidance and Counselling Teacher at SMAN 7 Sarolangun, then there are some suggestions that can be delivered in this study. Some suggestions are as follows:

1). In fostering teachers, principals as leaders can engage teachers in upgrading to broaden the teachers, directing teachers to perform tasks in learning, refrain from acts that are forced on teachers, trying to move the teacher in order to assess student learning outcomes, be wise in making decisions, facilitating a comfortable and supportive atmosphere for comfort in the work.

2 ). The school principal to provide security of the anxiety experienced by subordinates, keeping the attitude and actions, appreciate the work of subordinates by promotions, appreciate the work of subordinates with adequate facilities appreciate the work of subordinates with the opportunity to attend, hold meetings on a 


\section{International Journal of Science and Research (IJSR) \\ ISSN (Online): 2319-7064 \\ Index Copernicus Value (2013): 6.14 | Impact Factor (2015): 6.391}

regular basis, provide an example for subordinates, set a precise timetable for subordinates, solve existing problems in school appropriately, provide a clear task to subordinates.

\section{References}

[1] Abdul Rohim. (2011). Pembinaan Kompetensi Profesional Guru di SMP Assalam Cipondoh Tangerang. Skripsi. Tangerang: FIP UIN.

[2] Ali Imron. (1995). Pembinaan Guru Indonesia. Jakarta: PT Dunia Pustaka Raya.

[3] Andang. (2014). Manajemen dan Kepemimpinan Kepala Sekolah, Yogyakarta PT Ar-ruzz media, 2014

[4] Eiji, Ogawa. (1986). Manajemen Produksi Modern, Modern Production Management Pengalaman Jepang.Jakarta: FEUI dengan Lembaga SIUP. 1986

[5] Efastri, Rustono, Wibowo (2015). Keefektifan Konseling Kelompok Dengan Pendekatan Behavioral Untuk Mengurangi Perilaku Bullying, Perilaku Agresif. Prodi Bimbingan dan Konseling, Program Pascasarjana, Universitas Negeri Semarang, Indonesia. http://journal.unnes.ac.id/sju/index.php/jubk

[6] E.Mulyasa. (2007). Standar Kompetensi dan Sertifikasi Guru. Bandung: PT Remaja Rosdakarya.

[7] Ermis, Suryana. (2012) Bimbingan Konseling di Sekolah dan Madrasah.Palembang: Noer Fikri Offset

[8] Hartati Sukirman dkk. (2008). Administrasi dan Supervisi Pendidikan.Yogyakarta: UNY Press.

[9] Hartono dan Boy Soedarmadji. (2012). Psikolgi Konseling. Jakarta: Kencana Prenada Media Grup.

[10] Kadarman. (1991) Pengantar Ilmu Manajemen. Jakarta: PT.Gramedia pustaka utama, 1991 hal 11

[11] KBBI. (2005). Kamus Besar Bahasa Indonesia. Jakarta: Balai Pustaka.

[12] Munro,R.J Manthel.J.J Small. (1979). Penyuluhan (Konseling) Pendekatan Berdasarkan Keterampilan, Jakarta: Galia Indonesia, 1979.

[13] Prayitno, (2004). Seri Kegiatan Pendukung Konseling, P.1, UNP Padang 2004.

[14]Prayitno dan Erman Amti (2004), Dasar-dasar Bimbingan dan Konseling, (Jakarta: PT Rineka Cipta, 2004),

[15] Rohiat. (2008) Manajemen Sekolah. Bandung: PT. Rafika Aditama.

[16] Sabil Risaldi, Meaty H. Idris. (2015). Bimbingan dan konseling (implementasi pada pendidikan anak usia dini). Jakarta. PT Luxima Metro Media.

[17] Sugiyono. (2009). Metode Penelitian Kuantitatif Kualitatif dan $R \& D$. Bandung: Alfabeta.

[18] Sudarwan, Denim. (2009). Manajemen Dan Kepemimpinan Transformasional Kekepala Sekolahan, Jakarta: PT Rineka cipta.

[19] Sutarto. (2012). Manajemen Konseling Disekolah, Bengkulu LP2 STAIN Curup, 2012

[20] Syaiful, Sagala. (2010) Manajemen Strategik dalam Peningkatan Mutu Pendididkan. Bandung: Alfabeta.

[21] Taufik, (2009). Model-Model Konseling, UNP Padang.

[22] Wahjosumidjo. (2005). Kepemimpinan Kepala Sekolah. Jakarta : PT Raja Grafindo Persada.

[23] Wibawa, Sutoyo, Sugiyo, (2015) Pengembangan Model Konseling Kelompok Behaviour Dengan Teknik Modeling Untuk Meningkatkan Kedisiplinan Siswa Sma
Kabupaten Lamongan. Jurnal Bimbingan Konseling 4 (2) (2015). http://journal.unnes.ac.id/sju/index.php/jubk [24] Winardi. (2004). Manajemen Prilaku Organisasi, Jakarta:kencana prenada media group, 2004 